\title{
Preparation and NMR Analysis of 2,6-Heterodifunctional Halobenzenes as Precursors for Substituted Biphenyls
}

\author{
Monika Sienkowska, Vladimir Benin and Piotr Kaszynski* \\ Organic Materials Research Group, Department of Chemistry, Vanderbilt University, Nashville, TN 37235, USA
}

Received 5 October 1999; accepted 17 November 1999

\begin{abstract}
Preparation and complete characterization of 16 2,6-disubstituted halobenzenes, including nine new compounds, from two common starting materials is described. Seven of the new compounds contain one or two propylthio groups, which have been introduced in two ways. Direct reaction of arenediazonium salts with 1-propanethiolate gives yields comparable to those obtained in a three-step method through sulfonyl chlorides. The ${ }^{1} \mathrm{H}$ - and ${ }^{13} \mathrm{C}$ NMR chemical shifts of 17 1,2,3-trisubstituted benzenes have been correlated with the predicted values and the observed trends explained using commonly available modeling packages. (C) 1999 Elsevier Science Ltd. All rights reserved.
\end{abstract}

\section{Introduction}

2,6-Disubstituted halobenzenes (I) are relatively rare and constitute a class of important precursors to biologically active ${ }^{1,2}$ and naturally occurring compounds, ${ }^{3-5}$ intermediates for heterocycles, ${ }^{1,6-11}$ and building blocks for ortho-polysubstituted biphenyls. ${ }^{12-14}$ Most of the known halobenzenes I contain carbon-, nitrogen-, and oxygenbased substituents $\mathrm{X}$ and $\mathrm{Y}$. There is only a handful of compounds I with a sulfur substituent and their preparation is poorly documented. ${ }^{15,16}$

Our need for 2,6-disubstituted halobenzenes, especially those containing alkylthio substituents, stems from our research on heterocyclic compounds containing sulfur and nitrogen atoms. ${ }^{17}$ Their synthesis has been realized from halobenzenes 1-5 via corresponding biphenyls in which the functional groups $\mathrm{X}$ and $\mathrm{Y}$ are used to close heterocyclic rings at the later stages of synthesis. The choice of the halogen in 1-5 depends on the relative reactivity of the halobenzenes in the Ullmann reaction ${ }^{18}$ and the efficiency of the cross-coupling reactions.

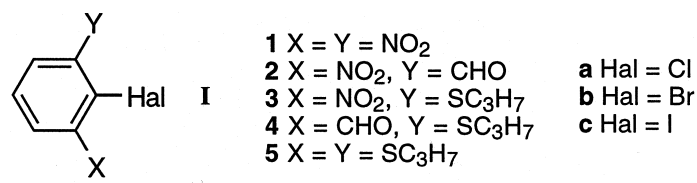

Compounds 1 and $\mathbf{2}$ have been reported in the literature, while halobenzenes $\mathbf{3}-\mathbf{5}$ containing an alkylthio substituent are unknown and require development of a reliable synthetic method. Most substituted halobenzenes I are conveniently

\footnotetext{
Keywords: aryl halide; aldehydes; sulfides; NMR; solvent effects.

* Corresponding author. Tel.: +1-615-322-3458; fax: +1-615-322-3458;

e-mail: piotr@ctrvax.vanderbilt.edu
}

obtained from 2,6-dinitroaniline ${ }^{19}$ (6) or anhydro-2hydroxymercuri-3-nitrobenzoic acid ${ }^{20}(7)$ whose syntheses are well described in the literature and which are also available commercially. Other more specific methods for preparation of halobenzenes I include electrophilic nitration, halogenation or chlorosulfonation ${ }^{15}$ of disubstituted benzenes followed by separation of isomers. orthoLithiation of 1,3-disubstituted benzenes followed by halogenation provides an alternative method for generation of some 2,6-disubstituted halides. ${ }^{3,21}$

Here we describe the synthesis and complete characterization of several halobenzenes $\mathbf{2}-\mathbf{5}$ from commercially available precursors.

\section{Results and Discussion}

The synthetic strategy relies on readily available 2,6dinitroaniline ${ }^{19}(6)$ and anhydro-2-hydroxymercuri-3-nitrobenzoic $\operatorname{acid}^{20}(\mathbf{7})$. Diazotization of aniline 6 followed by
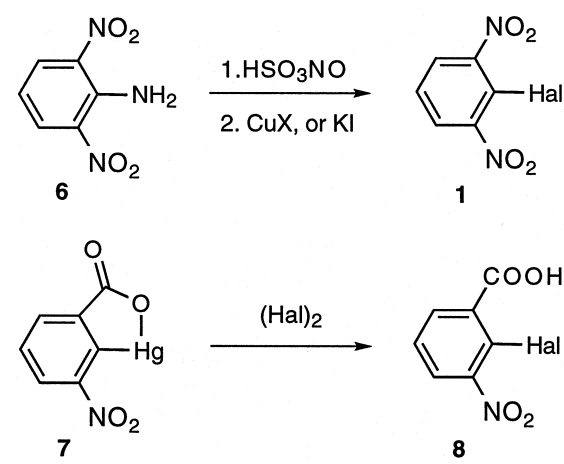

Scheme 1. a, $\mathrm{Hal}=\mathrm{Cl} ; \mathbf{b}, \mathrm{Hal}=\mathrm{Br} ; \mathbf{c}, \mathrm{Hal}=1$. 


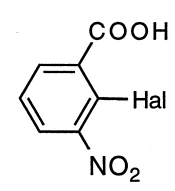

8

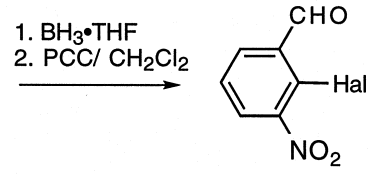

2
Scheme 2.

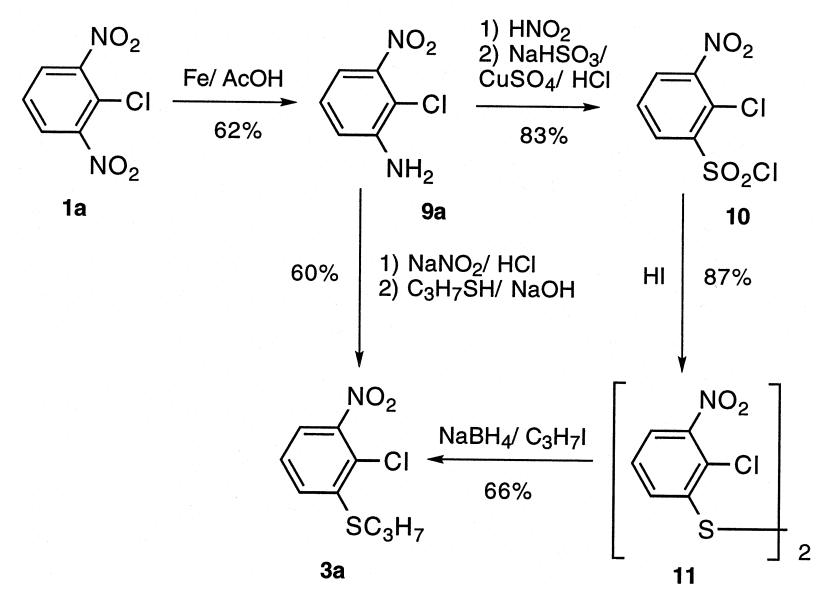

Scheme 3.

reactions with the appropriate cuprous halide or $\mathrm{KI}$ give access to 2,6-dinitrohalobenzene (1), ${ }^{22}$ a precursor to derivatives $\mathbf{3}$ and $\mathbf{5}$ (Scheme 1). Reaction of anhydride $\mathbf{7}$ with a halogen under basic conditions yields the corresponding halobenzoic acid $\mathbf{8},{ }^{23}$ which is a convenient precursor to aldehydes $\mathbf{2}$ and $\mathbf{4}$.

Preparation of benzaldehydes $2 \boldsymbol{a}$ and $\mathbf{2 b}$. 2-Halo-3-nitrobenzaldehydes $\mathbf{2} \mathbf{a}^{24}$ and $\mathbf{2} \mathbf{b}^{6}$ were prepared according to modified literature procedures by reduction of acid $\mathbf{8}$ and partial oxidation of the resulting alcohol (Scheme 2). Acid 8 was conveniently reduced with $\mathrm{BH}_{3}$. THF complex instead of a borane gas in diglyme $(\mathbf{8 b})^{6}$ or $\mathrm{NaBH}_{4}$ used in reduction of a mixed anhydride of $\mathbf{8 a} .{ }^{24}$ Oxidation of the intermediate carbinol to aldehyde $\mathbf{2}$ was accomplished using PCC in place of Swern conditions $(\mathbf{2 a})^{24}$ or activated $\mathrm{MnO}_{2}(\mathbf{2 b}){ }^{6}$
The reduction-oxidation sequence of $\mathbf{8}$ gives $\mathbf{2}$ in about $75 \%$ overall yield and constitutes a convenient alternative to another procedure for preparation of $\mathbf{2 a}$ from 2-chloro-3nitrotoluene. ${ }^{25}$

Preparation of 2-chloro-3-nitrophenyl propyl sulfide $3 \boldsymbol{a}$. Partial reduction of 2,6-dinitrochlorobenzene (1a) with electrolytic grade fine iron powder in acetic acid, according to a literature procedure, ${ }^{26}$ gave amine $9 \mathbf{a}$ in $62 \%$ yield (Scheme 3). ${ }^{27} \mathrm{~A}$ similar yield was obtained for analogous reduction of dinitroiodobenzene (1c) to the corresponding amine 9c. Diazotization of amine 9a and conversion to sulfonyl chloride $\mathbf{1 0}$ was accomplished in $83 \%$ crude yield according to a general literature procedure for an analogous compound. $^{26}$ The chloride was also obtained by direct chlorosulfonation of 2-chloronitrobenzene, according to patent literature. ${ }^{15}$ Crude sulfonyl chloride $\mathbf{1 0}$ was subsequently transformed to disulfide $\mathbf{1 1}$ under general conditions using hydroiodic acid. ${ }^{28}$ The disulfide was converted to 2-chloro-3-nitropropylthiobenzene (3a) using mild reductive alkylation conditions described for a similar compound. ${ }^{29}$ Thus, treatment of disulfide $\mathbf{1 1}$ with $\mathrm{NaBH}_{4}$ in ethanol generated the corresponding thiolate in situ, which was subsequently alkylated with propyl iodide to give sulfide $\mathbf{3 a}$.

Alternatively, a direct conversion of aniline 9a to the sulfide 3a was successfully achieved using a modified literature procedure. ${ }^{30}$ Aniline 9a was diazotized and the diazonium salt was subsequently reacted with aqueous sodium propanethiolate. The initially formed thiodiazene ${ }^{31}$ was thermally decomposed by heating the reaction mixture in the presence of a nickel salt. The sulfide 3a was isolated in $60 \%$ yield based on 9a which compares to $48 \%$ obtained in the previous three-step procedure. The product, sulfide $\mathbf{3 a}$, was found to be unstable to long-term storage at ambient temperature.

Synthesis of 2-bromo-3-propylthiobenzaldehyde $\mathbf{4 b}$. Initial attempts at conversion of the aldehyde $\mathbf{2 b}$ to 2-bromo-3propylthiobenzaldehyde (4b) using a general method ${ }^{32}$ were unsuccessful. Reduction of $\mathbf{2 b}$ with $\mathrm{SnCl}_{2}$ followed by diazotization and treatment with propanethiol gave a major product, isolated in $40 \%$ yield, which was identified as the corresponding thiodiazene, based on ${ }^{1} \mathrm{H}$ NMR analysis. Attempts at thermal decomposition of the thiodiazene to

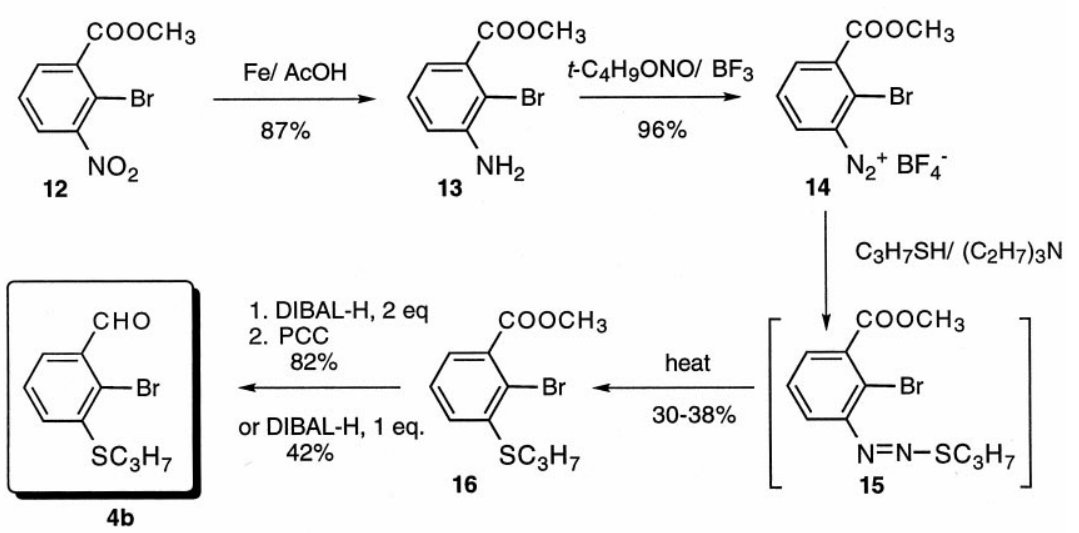




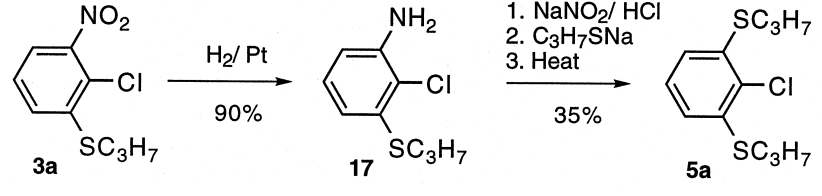

Scheme 5.

the desired sulfide $\mathbf{4 b}$ resulted in intractable materials only. Since the presence of the aldehyde group was suspected to complicate the formation of sulfide $\mathbf{4 b}$, it was decided to introduce the propylthio group before the aldehyde functionality.

Bromo acid $\mathbf{8 b}$ was converted into its methyl ester $\mathbf{1 2}$ using a standard method with $\mathrm{PCl}_{5}$ (or $\mathrm{SOCl}_{2}{ }^{1}$ ) followed by methanolysis. The nitro group in $\mathbf{1 2}$ was reduced with iron powder to form amino ester $\mathbf{1 3}$ (Scheme 4), while catalytic reduction over Pt gave methyl 3-aminobenzoate as the sole product. The subsequent transformation of amine $\mathbf{1 3}$ to the corresponding sulfide was accomplished using the singlestep method (cf. preparation of 3a) under neutral nonaqueous conditions best suited for the ester functionality. Thus, amine 13 was converted to diazonium tetrafluoroborate $\mathbf{1 4}$ with $t$-butyl nitrite under anhydrous conditions, ${ }^{33}$ which was reacted with propanethiol in acetonitrile in the presence of triethylamine. The reaction mixture was refluxed and the initially formed diazene $\mathbf{1 5}$ was thermally decomposed to yield propylthio ester $\mathbf{1 6}$ accompanied by about $50 \%$ of the deamination product, methyl 2-bromobenzoate. The progress of the reaction could be followed by ${ }^{1} \mathrm{H}$ NMR monitoring the position of the $\alpha$ methylene group triplet, which is shifted downfield by ca. $0.5 \mathrm{ppm}$ in $\mathbf{1 5}$ relative to that in $\mathbf{1 6}$. The choice of the solvent was based on the reported higher yields for the formation of the desired sulfides in acetonitrile as compared to other solvents. ${ }^{34}$

The overall yield of the ester $\mathbf{1 6}$ is $30-38 \%$ based on the starting amine 13.

Reduction of the ester 16 with 2 equiv. of DIBAL-H followed by PCC oxidation furnished the desired aldehyde 4b in $82 \%$ yield. Direct preparation of the aldehyde by partial reduction of ester $\mathbf{1 4}$ with 1 equiv. of DIBAL-H was less successful and the aldehyde was obtained in a moderate yield only.
Preparation of 2,6-bispropylthiohalobenzenes $\mathbf{5 a}$ and $\mathbf{5 c}$. 2-Chloro-3-nitro-propylthiobenzene (3a) was used as precursor for chloride 5a and the synthesis is shown in Scheme 5. The nitro group in 3a was catalytically reduced to the amine 17, which was converted to $\mathbf{5 a}$ in a one-pot reaction involving direct substitution of the diazonium group with a propylthio functionality via a thiodiazene intermediate (vide supra). The overall yield for $\mathbf{5 a}$ is $35 \%$ based on amine 17.

The iodide 5c, with enhanced reactivity towards Ullmann coupling reaction, was prepared in a sequence of reactions shown in Scheme 6. In an adaptation of an earlier procedure, ${ }^{35}$ 2,6-dichloroaniline was oxidized to 2,6-dichloronitrobenzene (18) with peroxyacetic acid according to a general method. ${ }^{36}$ Subsequent reaction of $\mathbf{1 8}$ with an ethanolic solution of 1-propanethiolate resulted in a double substitution to yield 2,6-bispropylthionitrobenzene (19) in analogy to a similar literature procedure. ${ }^{37}$ The combined yield for 19 was $28 \%$ based on the starting amine. Reduction of the nitro group followed by diazotization of the resulting amine 20 and reaction with KI furnished the desired iodide 5c. The overall yield for the preparation of $\mathbf{5 c}$ was about $8 \%$ based on 2,6-dichloroaniline which is comparable to the yield of the chloro analog $\mathbf{5 a}$ obtained via a different route from 1a.

\section{NMR Spectroscopy}

${ }^{1} \mathrm{H}$ NMR spectra of 1,2,3-trisubstituted benzenes exhibit a characteristic first order pattern of doublets of doublets for the $\mathrm{H}(4)$ and $\mathrm{H}(6)$ protons and a triplet or pseudo-triplet for the H(5) hydrogen. Compounds $\mathbf{5 a}$ and $\mathbf{1 6}$ are exceptions, showing second order spectra. The ${ }^{3} J_{\mathrm{HH}}$ coupling constants in the benzene ring are typically about $7.9 \mathrm{~Hz}$ and ${ }^{4} J_{\mathrm{HH}}$ couplings are about $1.4 \mathrm{~Hz}$. The structural assignment of the aromatic proton resonances was based on the relative chemical shifts (CS) calculated using empirical substituent chemical shift parameters (SCSP). The results collected in Table 1 show that while CS for some compounds correspond very closely to the predicted values (e.g. 5a, $\mathbf{5 c}$ and 17), for some others the discrepancies are large, reaching $-1.8 \mathrm{ppm}(\mathbf{1 c})$. These differences between the calculated and experimental CS may be related to either steric interactions or solvent effects, since SCSP were developed largely for strain-free monosubstituted benzenes in $\mathrm{CDCl}_{3}$

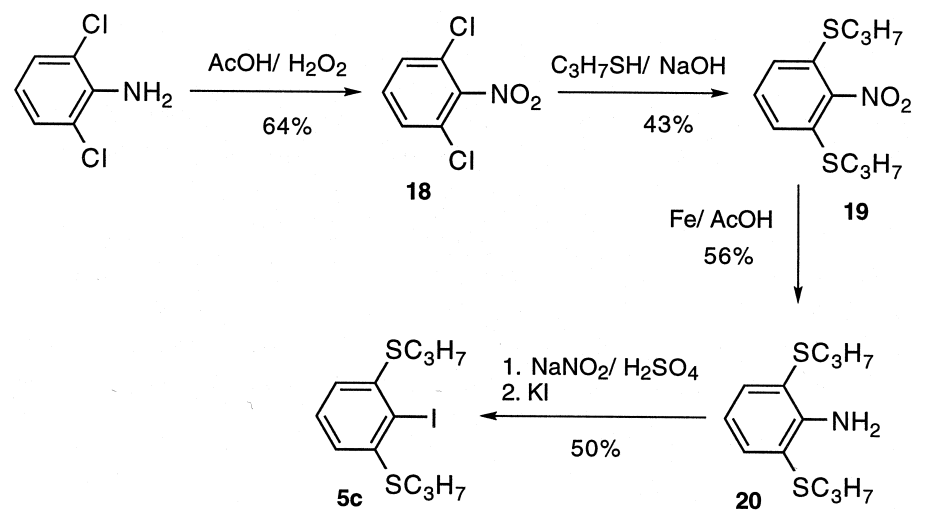




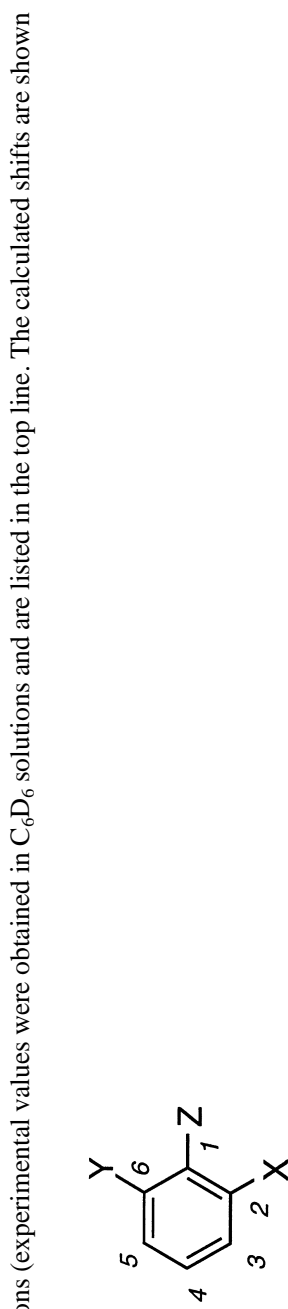

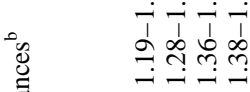

年

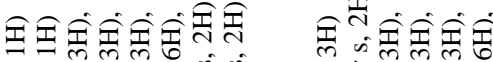

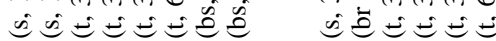

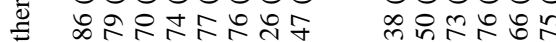

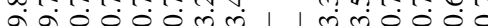

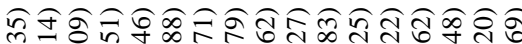

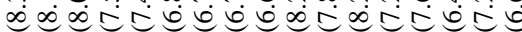

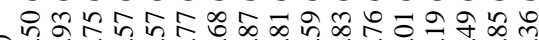
空

㒰丞 丞

f.

(1)

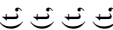

min

空空全要

हैं हैं हैं

किष

$-1-1$

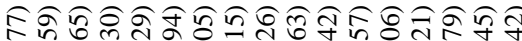

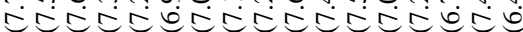

m mo

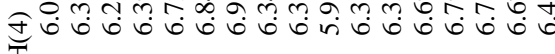

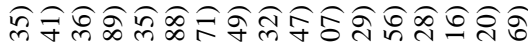

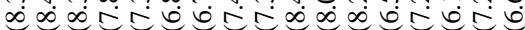

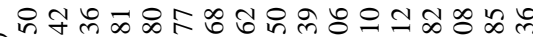

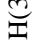

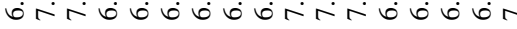

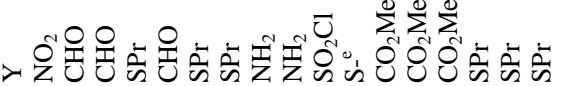

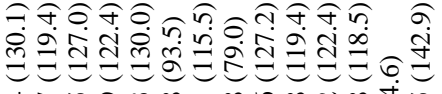

ตํ.

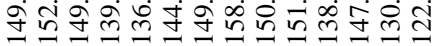

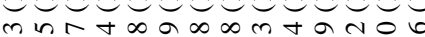

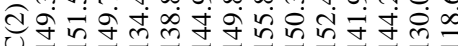

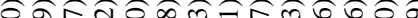

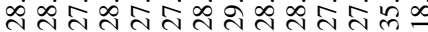
$m-n m a n n$ Nonm

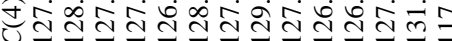

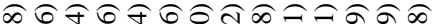

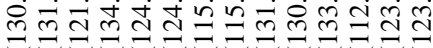

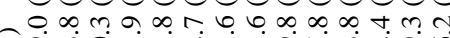

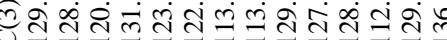

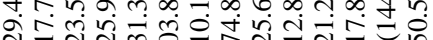

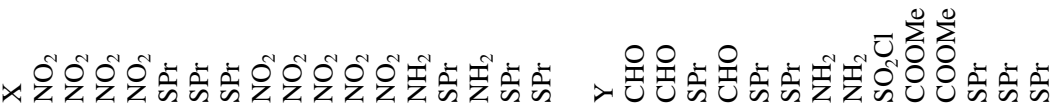

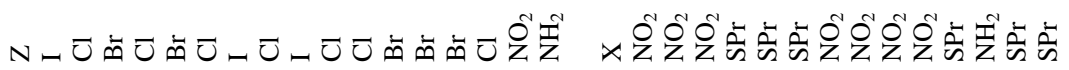
$\sum_{0}^{0}$

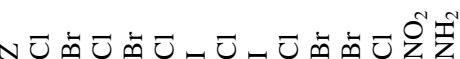



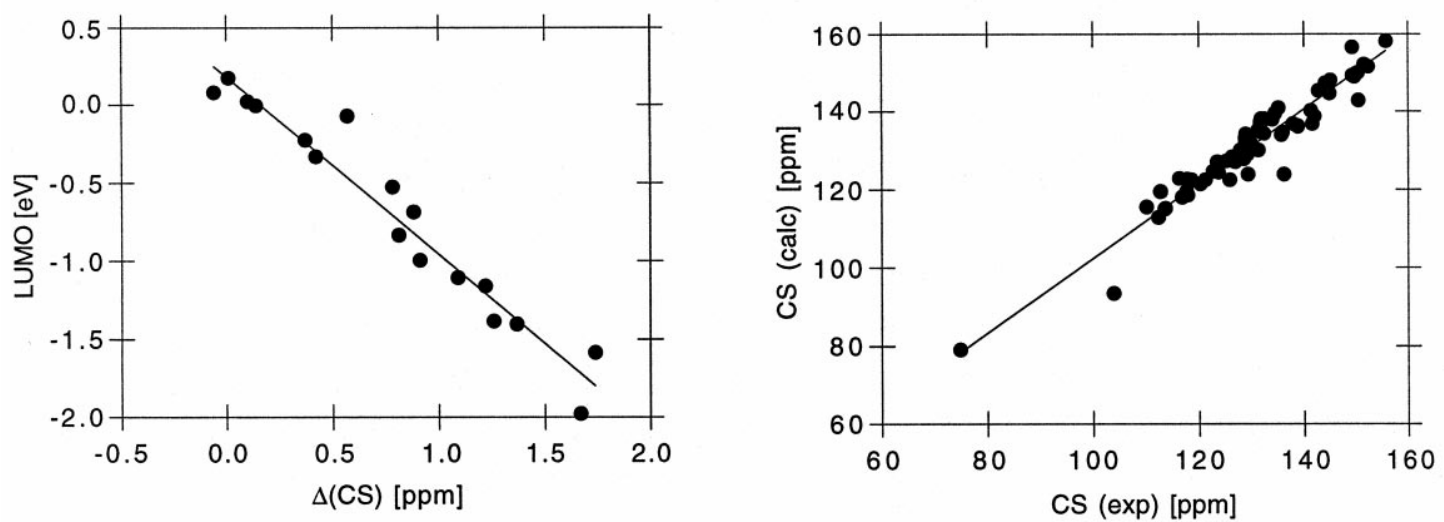

Figure 1. NMR chemical shifts: (a) correlation of the difference between calculated and experimental ${ }^{1} \mathrm{H}$ chemical shifts $(\Delta(\mathrm{CS}))$ and the energy of the LUMO; (b) correlation of experimental (exp) and calculated (calc) ${ }^{13} \mathrm{C}$ chemical shifts (CS). Best fit lines: (a) $y=0.18-x \times 1.14, r=0.971$; (b) $y=7.10+x \times 0.95$ $(r=0.964)$ or $y=x \times 1.01(r=0.962)$.

as the solvent. ${ }^{38}$ A closer inspection of Table 1 shows a trend between the magnitude of the CS differences and the number and strength of electron withdrawing substituents in each compound in the series. Thus, the more electron deficient the ring, the more shielded the protons are.

The observed trend is best explained by non-equivalent solvation of the analyte molecule by benzene. ${ }^{39}$ The $\pi$ interactions with benzene and the resulting anisotropic shielding of aromatic protons are expected to be stronger for the more electron deficient derivatives. The magnitude of the shielding should then approximately correlate with the energy of the LUMO localized on the aromatic ring, which is a rough reflection of electron density in the ring. Indeed, the LUMO energies listed in Table 1 correlate surprisingly well with the observed differences in chemical shifts, $\Delta(\mathrm{CS})$, as shown for the $\mathrm{H}(4)$ protons in Fig. 1a. The $\mathrm{H}(4)$ protons are least affected by possible conformational changes imposed by the steric congestion of the three substituents, and the correlation factor $r$ is higher (0.971) than that when all protons are included in the correlation $(r=0.919)$. When the two most outlying values attributed to protons in the ortho positions to $\mathrm{SPr}$ in $\mathbf{2 0}$ and $\mathrm{NO}_{2}$ in $\mathbf{1 0}$ are removed, the $r$ is increased to 0.951 .

The structural assignment of the ${ }^{13} \mathrm{C}$ NMR signals was made based on relative intensity of the signals and best fit to the predicted values (Table 1). In contrast to ${ }^{1} \mathrm{H}$ NMR, ${ }^{13} \mathrm{C}$ spectra show no significant solvent effect, which is consistent with a smaller effect of the magnetic anisotropy on the shielding of carbon nuclei $(<2 \mathrm{ppm})$ than the protons. ${ }^{38}$ The experimental chemical shifts correlate well with those predicted using standard SCSP, as shown in Fig. 1b. The largest deviation from the predicted values are observed for the chemical shifts of $\mathrm{C}(1)-\mathrm{I}$ in $\mathbf{5 c}(-10.3 \mathrm{ppm})$ and $\mathrm{C}(3)-\mathrm{H}$ in $20(-12.4 \mathrm{ppm})$. With these two points removed, the mean difference is $+1.4 \mathrm{ppm}$ and STD is $2.8 \mathrm{ppm}$ for the remaining 73 pairs of chemical shifts in the series of compounds. This is a rather surprisingly good correlation considering the steric congestion in these 1,2,3-trisubstituted benzene derivatives.

The steric interactions do, however, influence the chemical shift and this is evident from the systematic upfield shift of the ${ }^{13} \mathrm{C}$ NMR resonance of the para carbon atom relative to the nitro group by about $5 \mathrm{ppm}$, while the ipso carbon is little affected. This was observed previously in 2-nitro- $m$ xylene and attributed to inhibition of resonance of the nitro group with the benzene ring. ${ }^{40}$ The ipso carbon atom in aniline derivative $\mathbf{2 0}$ shows a downfield deviation of $7.6 \mathrm{ppm}$ from the predicted value, which is consistent with similar observations in other 2,6-derivatives of aniline. ${ }^{41}$

\section{Conclusions}

Commercially available 2,6-dinitroaniline (6), mercuriobenzoic acid 7, and dichloroaniline serve as convenient precursors to a variety of previously reported and new 1,2,3-trisubstituted halobenzene derivatives. Particular emphasis was placed on the preparation of the alkylthio derivatives, which were virtually unknown in the literature. Out of the two methods used in their synthesis, the direct conversion of arylamines to the corresponding aryl alkyl sulfides was found to be more convenient. This previously reported method was successfully extended to the preparation of several new compounds with different functionalities and modified to be compatible with either aqueous or anhydrous media. The results of Ullmann coupling reactions will be reported elsewhere.

The structural assignment of NMR chemical shifts was based on empirical prediction using the additivity of substituent chemical shift parameters (SCSP). The relatively large number of completely characterized 1,2,3-trisubstituted derivatives allowed for generalization of the observed trends and anomalies. Thus, the results of NMR analysis performed in benzene- $d_{6}$ are consistent with expectations. ${ }^{1} \mathrm{H}$ NMR spectra are significantly affected by solvent, while the ${ }^{13} \mathrm{C}$ chemical shifts show low sensitivity to solvent and steric effects. The solvent effect observed in ${ }^{1} \mathrm{H}$ NMR spectra was attributed to electronic interactions with the solvent and correlated with the LUMO energy of the analyte. The analysis of the NMR data using ChemDraw and CAChe programs provides an example of application of simple and commonly available computational and modeling packages to physical-organic problems. 


\section{Experimental}

Melting points were performed on a Mel-temp apparatus and are uncorrected. NMR spectra were obtained on a Bruker instrument at the $300 \mathrm{MHz}$ field $\left({ }^{1} \mathrm{H}\right.$ spectra) and $75 \mathrm{MHz}$ field $\left({ }^{13} \mathrm{C}\right.$ spectra) in $\mathrm{C}_{6} \mathrm{D}_{6}$ and referenced to the solvent peak at $7.15 \mathrm{ppm}\left({ }^{1} \mathrm{H}\right)$ and $128.0 \mathrm{ppm}\left({ }^{13} \mathrm{C}\right)$, unless specified otherwise. The chemical shifts and their partial assignments are shown in Table 1. IR spectra of samples deposited from $\mathrm{CH}_{2} \mathrm{Cl}_{2}$ solutions on a $\mathrm{NaCl}$ disc were recorded using ATI Mattson, Genesis Series FTIR instrument. Mass spectrometry was performed using HewlettPackard 5890 instrument (GCMS). Elemental analysis was provided by Atlantic Microlab, Norcross, Georgia. Fine electrolytic iron powder was obtained from Fischer Scientific.

Chemical shifts were calculated using ChemDraw 5.0 Ultra program (CambridgeSoft Co.). Simulation of second order spectra was done using PC NMR 1.0 program from Serena Software. Quantum-mechanical calculations were performed using the AM1 method in the CAChe 3.7 suite of programs (CAChe Scientific, Inc.). No symmetry constraints were used and molecular geometries were fully optimized with the keyword GNORM $=0$.

2,6-Dinitroiodobenzene (1c) ${ }^{22}$ Sodium nitrite $(0.83 \mathrm{~g}$, $12.00 \mathrm{mmol}$ ) was added portionwise to sulfuric acid $(9 \mathrm{~mL})$ and the mixture was stirred and heated to $70^{\circ} \mathrm{C}$ until the full dissolution of the solid. The resultant solution was cooled below $40^{\circ} \mathrm{C}$. 2,6-Dinitroaniline (6, $2.00 \mathrm{~g}$, $11.00 \mathrm{mmol})$, dissolved in AcOH (22 mL), was added dropwise to the sodium nitrite solution while the temperature was maintained below $40^{\circ} \mathrm{C}$. The stirring was continued for an additional $0.5 \mathrm{~h}$, then the reaction mixture was poured into a stirred solution of $\mathrm{KI}(2.00 \mathrm{~g}, 12.00 \mathrm{mmol})$ in water $(20 \mathrm{~mL})$ at $70^{\circ} \mathrm{C}$. The resultant mixture was stirred for $15 \mathrm{~min}$ then poured into $200 \mathrm{~mL}$ of water. The solid material was filtered, washed with water and dried to give $2.80 \mathrm{~g}$ ( $87 \%$ yield) of product which was used without further purification: MS m/e (relative intensity) $294\left(\mathrm{M}^{+}, 100\right), 75$ (65).

2-Chloro-3-nitrobenzaldehyde (2a). ${ }^{24}$ Acid 8a (0.505 g, $2.51 \mathrm{mmol})$ was dissolved in dry THF $(3 \mathrm{~mL})$. A solution of $\mathrm{BH}_{3} \cdot \mathrm{THF}$ complex $(1 \mathrm{M}, 4.6 \mathrm{~mL})$ was added at a moderate rate under nitrogen and the solution was stirred for $12 \mathrm{~h}$ at ambient temperature. The reaction mixture was poured into aqueous $\mathrm{HCl}(4 \%, 110 \mathrm{~mL})$ and the organic components were extracted with diethyl ether. The organic layer was dried $\left(\mathrm{Na}_{2} \mathrm{SO}_{4}\right)$ and the solvent removed under reduced pressure to yield $0.444 \mathrm{~g}$ (95\% yield) of crude 2-chloro-3-nitrobenzyl alcohol (pale yellow crystals): $\mathrm{mp}$ $67^{\circ} \mathrm{C}$ (lit. ${ }^{24} 67-70^{\circ} \mathrm{C}$ ). Without further purification, the alcohol $(0.441 \mathrm{~g}, 2.35 \mathrm{mmol})$ was dissolved in methylene chloride $(30 \mathrm{~mL})$ and PCC $(0.494 \mathrm{~g}, 2.29 \mathrm{mmol})$ was added. The solution turned black almost immediately. Stirring was continued for $2.5 \mathrm{~h}$ under nitrogen and the resulting mixture was passed through a silica gel plug using additional methylene chloride for flushing. The solvent was removed under reduced pressure to leave $0.355 \mathrm{~g}(76 \%$ overall yield $)$ of the product: $\mathrm{mp} 91-92^{\circ} \mathrm{C}$ (lit. $\left.^{24} 93-95^{\circ} \mathrm{C}\right)$.
2-Bromo-3-nitrobenzaldehyde $(\mathbf{2 b}) .{ }^{6} \mathbf{2 b}$ was obtained in an analogous way to the preparation of $\mathbf{2 a}$. Reduction of 2-bromo-3-nitrobenzoic acid (8b, $4.96 \mathrm{~g}, 20.00 \mathrm{mmol})$ gave $3.60 \mathrm{~g}$ (77\% yield) of crude 2-bromo-3-nitrobenzyl alcohol which upon oxidation furnished $3.73 \mathrm{~g}$ (76\% overall yield) of the aldehyde. The crude aldehyde was purified on a silica gel column (hexane/EtOAc in 5:1 ratio) to yield a pale yellow solid: $\mathrm{mp} 107-108^{\circ} \mathrm{C}$ (lit. ${ }^{6} 108-109^{\circ} \mathrm{C}$ ). Anal. Calcd for $\mathrm{C}_{7} \mathrm{H}_{4} \mathrm{BrNO}_{3}$ : C, 36.55; $\mathrm{H}, 1.75 ; \mathrm{N}, 6.09$. Found: $\mathrm{C}$, 36.67 ; H, 1.67; N, 5.99 .

1-Chloro-2-nitro-6-propylthiobenzene (3a). Method A: Disulfide 11 (7.49 g, $20.0 \mathrm{mmol}$ ) was dissolved in pyridine $(130 \mathrm{~mL})$ and the solution was cooled to $5-10^{\circ} \mathrm{C}$. A slurry of sodium borohydride $(7.30 \mathrm{~g})$ in absolute ethanol $(130 \mathrm{~mL})$ was added portionwise to the stirred solution and stirring was continued for $10 \mathrm{~min}$. Propyl iodide (16.95 g, $100 \mathrm{mmol}, 9.7 \mathrm{~mL}$ ), dissolved in 95\% ethanol, was then added dropwise, and, after $1.5 \mathrm{~h}$ additional stirring, the mixture was poured into water. The product was extracted with ether, the organic layer was dried and the solvent was evaporated. The residue was passed through a short silica gel column (hexane/ $\mathrm{CH}_{2} \mathrm{Cl}_{2}$ in $3: 1$ ratio) giving $6.13 \mathrm{~g}$ (66\% yield) of a light yellow oil: IR 3075, 2965, 2931, 1530, $1355 \mathrm{~cm}^{-1}$; MS m/e (relative intensity) 233 $\left((\mathrm{M}+2)^{+}, 37\right), 231\left(\mathrm{M}^{+}, 95\right), 191$ (37), 189 (100). Anal. Calcd for $\mathrm{C}_{9} \mathrm{H}_{10} \mathrm{ClNO}_{2} \mathrm{~S}$ : C, 46.66; H, 4.35; N, 6.04. Found: C, 46.48; H, 4.35; N, 6.00.

Method B: A suspension of well-ground aniline 9a $(2.03 \mathrm{~g}$, $11.76 \mathrm{mmol})$ in conc. $\mathrm{HCl}(12.5 \mathrm{~mL})$ was stirred at $70^{\circ} \mathrm{C}$ until the aniline was converted to the hydrochloride salt (change of color from intense yellow to a very pale yellow). The suspension was cooled to $0-5^{\circ} \mathrm{C}$ and a solution of sodium nitrite $(1.05 \mathrm{~g}, 15.43 \mathrm{mmol})$ in water $(2.5 \mathrm{~mL})$ was added dropwise. Stirring was continued for an additional $0.5 \mathrm{~h}$ at the same temperature at which point the mixture was vacuum filtered. The filtrate was rapidly added to a solution of $\mathrm{NaOH}(0.54 \mathrm{~g}, 13.23 \mathrm{mmol})$ and 1-propanethiol $(1.00 \mathrm{~g}, 13.23 \mathrm{mmol}, 1.23 \mathrm{~mL})$ in water $(12 \mathrm{~mL})$ containing a few crystals of solid $\mathrm{Ni}(\mathrm{AcO})_{2}$. The resultant mixture was stirred for $0.5 \mathrm{~h}$ at ambient temperature followed by $12 \mathrm{~h}$ at $70^{\circ} \mathrm{C}$. The organic materials were extracted with methylene chloride, the organic layer was dried $\left(\mathrm{Na}_{2} \mathrm{SO}_{4}\right)$ and the solvent removed under reduced pressure. The crude mixture was separated on a silica gel column (hexane $/ \mathrm{CH}_{2} \mathrm{Cl}_{2}$ in $3: 1$ ratio) to yield the product as a light yellow oil (1.62 g, 60\%), identical to that obtained in Method A.

2-Bromo-3-propylthiobenzaldehyde (4b). Method A: Ester $16(0.555 \mathrm{~g}, 1.92 \mathrm{mmol})$ was dissolved in dry toluene $(5 \mathrm{~mL})$ and the solution was cooled to $-78^{\circ} \mathrm{C}$. DIBAL-H (3.84 mmol, $2.53 \mathrm{~mL}$ of $25 \mathrm{wt} \%$ in toluene) was added dropwise and stirring continued for $1 \mathrm{~h}$ at $-78^{\circ} \mathrm{C} .1 \mathrm{~N} \mathrm{HCl}$ $(1.3 \mathrm{~mL})$ was added followed by ether $(25 \mathrm{~mL})$ and the mixture was warmed to ambient temperature. More ether and $1 \mathrm{~N} \mathrm{HCl}$ were added and the organic layer was separated and dried $\left(\mathrm{Na}_{2} \mathrm{SO}_{4}\right)$. The solvent was evaporated to give $0.450 \mathrm{~g}$ (90\% yield) of 2-bromo-3-propylthiobenzyl alcohol as white crystals: $\mathrm{mp} 72.5-74^{\circ} \mathrm{C} ;{ }^{1} \mathrm{H}$ NMR $\delta 0.77(\mathrm{t}$, $J=7.4 \mathrm{~Hz}, 3 \mathrm{H}), 1.24(\mathrm{t}, J=6.0 \mathrm{~Hz}, 1 \mathrm{H}), 1.36-1.46(\mathrm{~m}$, 2H), 2.47 (t, $J=7.3 \mathrm{~Hz}, 3 \mathrm{H}), 4.72(\mathrm{~d}, J=5.9 \mathrm{~Hz}, 2 \mathrm{H}), 6.84$ $\left(\mathrm{dd}, J_{1}=7.8 \mathrm{~Hz}, J_{2}=1.4 \mathrm{~Hz}, 1 \mathrm{H}\right), 6.96(\mathrm{t}, J=7.7 \mathrm{~Hz}, 1 \mathrm{H})$, 
$7.20\left(\mathrm{dd}, J_{1}=7.7 \mathrm{~Hz}, J_{2}=1.2 \mathrm{~Hz}, 1 \mathrm{H}\right) ;{ }^{13} \mathrm{C} \mathrm{NMR} \delta 13.5$, 22.0, 34.9, 65.1, 122.7, 124.6, 126.2, 127.6, 139.7, 142.0. Without further purification, the alcohol $(0.445 \mathrm{~g}$, $1.70 \mathrm{mmol})$ was dissolved in methylene chloride $(30 \mathrm{~mL})$ and PCC (0.403 g, $1.87 \mathrm{mmol})$ was added. The solution turned black almost immediately. Stirring was continued for $2.5 \mathrm{~h}$ under nitrogen and the resulting mixture was passed through a silica gel plug using additional methylene chloride for flushing. The solvent was removed under reduced pressure to leave $0.404 \mathrm{~g}(91 \%$ yield $)$ of the crude product which was short-path distilled $\left(150^{\circ} \mathrm{C} / 0.07\right.$ torr $)$ to yield $0.362 \mathrm{~g}$ (73\% overall yield) of aldehyde 4b: IR 2963, 2930, 2871, 1726, 1689, 1554, 1371, 1234, 1145, $779 \mathrm{~cm}^{-1}$; MS $m / e$ (relative intensity) $260\left((\mathrm{M}+2)^{+}, 100\right), 258\left(\mathrm{M}^{+}\right.$, 98), 218 (82), 217 (47), 216 (83), 215 (39), 137 (55), 136 (59), 108 (37).

2,4-Dinitrophenylhydrazone: $\mathrm{mp} 180-180.5^{\circ} \mathrm{C}$. Anal. Calcd for $\mathrm{C}_{16} \mathrm{H}_{15} \mathrm{BrN}_{4} \mathrm{O}_{4} \mathrm{~S}$ : C, 43.75; H, 3.44; N, 12.75 . Found: C, 43.86; H, 3.50; N, 12.54 .

Method B: Ester $16(0.11 \mathrm{~g}, 0.38 \mathrm{mmol})$ was dissolved in dry toluene $(1 \mathrm{~mL})$ and the solution was cooled to $-78^{\circ} \mathrm{C}$ (dry ice-acetone bath). DIBAL-H $(0.38 \mathrm{mmol}, 0.25 \mathrm{~mL}$ of 25 wt. \% in toluene) was added dropwise and stirring continued for $1 \mathrm{~h}$ at $-78^{\circ} \mathrm{C}$. $1 \mathrm{~N} \mathrm{HCl}(0.25 \mathrm{~mL})$ was then added followed by ether $(5 \mathrm{~mL})$ and the mixture was warmed to ambient temperature. More ether and $1 \mathrm{~N} \mathrm{HCl}$ were added and the organic layer was separated and dried. The solvent was removed under reduced pressure and the residue was separated on a silica gel column (benzene/hexane in 3:1 ratio) to yield the product as a yellow oil $(0.04 \mathrm{~g}, 42 \%$ yield).

2,6-Bis(propylthio)chlorobenzene (5a). A mixture of amine $17(0.58 \mathrm{~g}, 2.90 \mathrm{mmol})$ and conc. $\mathrm{HCl}(3.30 \mathrm{~mL})$ was stirred at $80^{\circ} \mathrm{C}$ for $15 \mathrm{~min}$. Water was added $(3.30 \mathrm{~mL})$ and the mixture was cooled to $0^{\circ} \mathrm{C}$ (ice-saltwater bath). A solution of $\mathrm{NaNO}_{2}(0.19 \mathrm{~g}, 3.20 \mathrm{mmol})$ in water $(1.30 \mathrm{~mL})$ was added dropwise and the mixture was stirred for $20 \mathrm{~min}$ at $0^{\circ} \mathrm{C}$. The resulting diazonium salt was added to a stirred solution of $\mathrm{NaOH}(0.13 \mathrm{~g}, 3.20 \mathrm{mmol})$ and 1-propanethiol $(0.24 \mathrm{~g}, 3.20 \mathrm{mmol}, 0.29 \mathrm{~mL})$ in water $(3.00 \mathrm{~mL})$ containing a few crystals of $\mathrm{Ni}\left(\mathrm{NO}_{3}\right)_{2}$. The resultant mixture was stirred for $0.5 \mathrm{~h}$ at ambient temperature and then for $12 \mathrm{~h}$ at $60^{\circ} \mathrm{C}$. Organic materials were extracted with methylene chloride and the residue after removal of the solvent was passed through a silica gel column (hexane/ $\mathrm{CH}_{2} \mathrm{Cl}_{2}$ in $5: 1$ ratio) to yield $0.26 \mathrm{~g}(35 \%$ yield) of a white solid of the chloride: $\mathrm{mp} 43-44^{\circ} \mathrm{C}$; IR 2965, 2933, 2872, 1562, 1453, 1432, 1389, $753 \mathrm{~cm}^{-1}$; MS $m / e$ (relative intensity) $262\left((\mathrm{M}+2)^{+}, 33\right), 260\left(\mathrm{M}^{+}, 78\right)$, 218 (58), 178 (42), 176 (100). Anal. Calcd for $\mathrm{C}_{12} \mathrm{H}_{17} \mathrm{ClS}_{2}$ : C, 55.26; H, 6.57. Found: C, 55.15; H, 6.50.

2,6-Bis(propylthio)iodobenzene (5c). Sodium nitrite $(0.25 \mathrm{~g}, 3.6 \mathrm{mmol})$ was added portionwise to sulfuric acid $(3.5 \mathrm{~mL})$ and the resultant mixture was stirred and heated to $70^{\circ} \mathrm{C}$ until full dissolution of the solid. The resultant colorless solution was then cooled to $0^{\circ} \mathrm{C}$. Aniline $20(0.79 \mathrm{~g}$, $3.27 \mathrm{mmol})$, dissolved in acetic acid $(6 \mathrm{~mL})$, was added dropwise to the sodium nitrite solution and the temperature was maintained at $0^{\circ} \mathrm{C}$ during the addition. Stirring was continued for an additional $0.5 \mathrm{~h}$ at the same temperature. At this point a solution of KI $(2.26 \mathrm{~g}, 13.5 \mathrm{mmol})$ in water $(20 \mathrm{~mL})$ was added quickly. The resultant mixture was stirred for an additional $20 \mathrm{~min}$ at $70^{\circ} \mathrm{C}$ and then poured into $150 \mathrm{~mL}$ of water. The organic materials were extracted with methylene chloride, the organic layer was dried $\left(\mathrm{MgSO}_{4}\right)$ and passed through a silica gel plug. The solvent was removed under reduced pressure and the resultant crude mixture was separated on a silica gel column (hexane) to yield the product as a white crystalline solid $(0.58 \mathrm{~g}, 50 \%$ yield). Additional purification was achieved via recrystallization from petroleum ether: $m p$ $64-65^{\circ} \mathrm{C}$; IR 2965, 2929, 2869, 1555, 1423, $751 \mathrm{~cm}^{-1}$; MS m/e (relative intensity) $352\left(\mathrm{M}^{+}, 100\right), 310$ (21), 268 (63). Anal. Calcd for $\mathrm{C}_{12} \mathrm{H}_{17} \mathrm{IS}_{2}$ : C, 40.91; H, 4.86. Found: C, 41.10; H, 4.85.

2-Chloro-3-nitroaniline $(\mathbf{9 a}){ }^{26}$ This compound was prepared according to the literature procedure. $^{26} 2,6$ Dinitrochlorobenzene (1a, $16.06 \mathrm{~g}, 80.0 \mathrm{mmol})$ was added to glacial acetic acid $(240 \mathrm{~mL})$ and the mixture heated to $120^{\circ} \mathrm{C}$. Fine iron powder $(13.0 \mathrm{~g})$ was added in portions and the mixture was heated at reflux for $2.5 \mathrm{~h}$. The hot reaction mixture was poured into cold water and the precipitate was filtered off and washed with cold water to give $8.58 \mathrm{~g}(62 \%$ yield) of the product as a yellow solid: $\mathrm{mp} 95^{\circ} \mathrm{C}$ (lit. $^{26}$ 95-96 $\left.{ }^{\circ} \mathrm{C}\right)$.

3-Nitro-2-iodoaniline (9c). 9c was obtained from 2,6dinitroiodobenzene (1c, $0.70 \mathrm{~g}, 2.40 \mathrm{mmol}$ ) as described for 1a. The crude material was extracted with $\mathrm{CH}_{2} \mathrm{Cl}_{2}$ and the extract was passed through a silica gel plug to give $0.40 \mathrm{~g}$ (63\% yield) of the aniline as a yellow solid: $\mathrm{mp}$ $101-102^{\circ} \mathrm{C}$; IR 3463, 3367, 1619, 1514, 1461, 793, $731 \mathrm{~cm}^{-1}$; MS m/e (relative intensity) $264\left(\mathrm{M}^{+}, 88\right), 218$ (42), 91 (100). Anal. Calcd for $\mathrm{C}_{6} \mathrm{H}_{5} \mathrm{IN}_{2} \mathrm{O}_{2}: \mathrm{C}, 27.30 ; \mathrm{H}$, $1.91 ; \mathrm{N}, 10.61$. Found: C, 27.52; H, 1.84; N, 10.55 .

Bis(2-chloro-3-nitrophenyl)disulfide (11). A suspension of well ground aniline $9 \mathrm{a}(2.52 \mathrm{~g}, 15.00 \mathrm{mmol})$ in conc. $\mathrm{HCl}(15 \mathrm{~mL})$ was cooled to $5-10^{\circ} \mathrm{C}$ and a solution of sodium nitrite $(1.30 \mathrm{~g}, 19.00 \mathrm{mmol})$ in water $(2.5 \mathrm{~mL})$ was added dropwise. Stirring was continued for $0.5 \mathrm{~h}$, after which the mixture was vacuum filtered and the filtrate was added, simultaneously with aq. $\mathrm{Na}_{2} \mathrm{SO}_{3} \quad(4.70 \mathrm{~g}$, $37.30 \mathrm{mmol}$, in $8 \mathrm{~mL}$ of water), to a stirred solution of $\mathrm{Na}_{2} \mathrm{SO}_{3} \quad(4.70 \mathrm{~g}, \quad 37.30 \mathrm{mmol})$ and $\mathrm{CuSO}_{4}(0.37 \mathrm{~g}$, $2.28 \mathrm{mmol})$ in $\mathrm{HCl}(35 \mathrm{~mL})$ and water $(8 \mathrm{~mL})$ at $3-5^{\circ} \mathrm{C}$. Stirring was continued for $0.5 \mathrm{~h}$ and the resulting precipitate was filtered off, washed with water and dried to give $3.20 \mathrm{~g}$ (83\% yield) of pure 2-chloro-3-nitrobenzenesulfonyl chloride (10): mp $73-74^{\circ} \mathrm{C}$ (lit. ${ }^{15} 76-78^{\circ} \mathrm{C}$ ).

A mixture of sulfonyl chloride $\mathbf{1 0}(0.75 \mathrm{~g}, 2.93 \mathrm{mmol})$ and $\mathrm{HI}(22.90 \mathrm{mmol}, 3.00 \mathrm{~mL}$ of $57 \mathrm{wt} \%)$ was stirred at $120^{\circ} \mathrm{C}$ for $3 \mathrm{~h}$. After cooling to ambient temperature, solid sodium bisulfite was added until all of the iodine was reacted. The product was then filtered off, washed abundantly with water and dried to give $0.48 \mathrm{~g}$ ( $87 \%$ yield) of the disulfide 11. An analytical sample was obtained by recrystallization from toluene: $\mathrm{mp} 175-178^{\circ} \mathrm{C}$ (lit. ${ }^{15} 179-181^{\circ} \mathrm{C}$ ). Anal. Calcd for $\mathrm{C}_{12} \mathrm{H}_{6} \mathrm{Cl}_{2} \mathrm{~N}_{2} \mathrm{O}_{4} \mathrm{~S}_{2}$ : C, 38.22; $\mathrm{H}, 1.60 ; \mathrm{N}, 7.43$. Found: C, 38.28; H, 1.63; N, 7.38. 
Methyl 2-bromo-3-nitrobenzoate (12). ${ }^{1}$ Acid 8 b $(5.30 \mathrm{~g}$, $21.50 \mathrm{mmol})$ was mixed in the solid state with $\mathrm{PCl}_{5}(4.48 \mathrm{~g}$, $21.50 \mathrm{mmol})$. The solid mixture was placed in an oil bath at $150^{\circ} \mathrm{C}$, where it quickly turned into liquid, with evolution of $\mathrm{HCl}$ gas. Stirring was continued for $5 \mathrm{~min}$ at $150^{\circ} \mathrm{C}$ followed by the removal of the byproduct, $\mathrm{POCl}_{3}$, under reduced pressure. The liquid was cooled to ambient temperature and $\mathrm{MeOH}(50 \mathrm{~mL})$ was added in one portion. A vigorous reaction ensued and the resultant solution was stirred at reflux for $1 \mathrm{~h}$. Solvent was removed under reduced pressure leaving the ester as a pale yellow solid (5.26 g, 94\% yield). The ester was recrystallized from ethanol to give $4.82 \mathrm{~g}$ (86\% yield) of white crystals: $\mathrm{mp} 74.5-76^{\circ} \mathrm{C}$ (lit. ${ }^{1} 76.5-$ $\left.77^{\circ} \mathrm{C}\right)$; IR 1737, 1528, 1427, 1363, 1292, 1274, 1210, $1137 \mathrm{~cm}^{-1}$.

Methyl 3-amino-2-bromobenzoate (13). ${ }^{11}$ Ester $\mathbf{1 2}$ $(3.00 \mathrm{~g}, 11.50 \mathrm{mmol})$ was dissolved in glacial acetic acid $(15 \mathrm{~mL})$ and the solution was heated to $120^{\circ} \mathrm{C}$. Reduced iron powder $(2.15 \mathrm{~g}, 38.60 \mathrm{mmol})$ was added in one portion and the mixture was stirred at $120^{\circ} \mathrm{C}$ for $2 \mathrm{~h}$. The hot mixture was poured into water, the organic materials were extracted with methylene chloride, and the solution was passed through a silica gel plug to give $2.30 \mathrm{~g}$ ( $87 \%$ yield) of the product as a light yellow oil, which was used without additional purification: MS m/e (relative intensity) 231 $\left((\mathrm{M}+2)^{+}, 96\right), 229\left(\mathrm{M}^{+}, 92\right), 200(88), 198$ (100), 90(72).

Methyl 2-bromo-3-propylthiobenzoate (16). Amine 15 $(0.37 \mathrm{~g}, 1.60 \mathrm{mmol})$ was dissolved in dry methylene chloride $(2 \mathrm{~mL})$ and cooled to $-15^{\circ} \mathrm{C}$. $\mathrm{BF}_{3} \cdot\left(\mathrm{C}_{2} \mathrm{H}_{5}\right)_{2} \mathrm{O}$ $(0.34 \mathrm{~g}, 2.30 \mathrm{mmol}, 0.30 \mathrm{~mL})$ was added dropwise as the temperature was maintained at $-15^{\circ} \mathrm{C}$. A precipitate separated and was redissolved by adding dry ether to the mixture. $t-\mathrm{C}_{4} \mathrm{H}_{7} \mathrm{ONO}(0.19 \mathrm{~g}, 1.90 \mathrm{mmol}, 0.22 \mathrm{~mL})$, in methylene chloride $(2 \mathrm{~mL})$ was added dropwise at $-15^{\circ} \mathrm{C}$ and stirring continued for $15 \mathrm{~min}$ at this temperature and then for $5 \mathrm{~min}$ at $5^{\circ} \mathrm{C}$ (ice-water bath). Pentane $(10 \mathrm{~mL})$ was added and the mixture was vacuum filtered. The solid was washed with cold ether and dried to give $0.48 \mathrm{~g}$ (91\% yield) of dry diazonium salt $14:{ }^{1} \mathrm{H}$ NMR (acetonitrile$\left.d_{3}\right) \delta 3.97(\mathrm{~s}, 3 \mathrm{H}), 7.99(\mathrm{t}, J=8.1 \mathrm{~Hz}, 1 \mathrm{H}), 8.59(\mathrm{dd}$, $\left.J_{1}=8.0 \mathrm{~Hz}, J_{2}=1.6 \mathrm{~Hz}, 1 \mathrm{H}\right), 8.67\left(\mathrm{dd}, J_{1}=8.5 \mathrm{~Hz}, J_{2}=\right.$ $1.5 \mathrm{~Hz}, 1 \mathrm{H})$.

Dry diazonium salt $14(0.30 \mathrm{~g}, 0.91 \mathrm{mmol})$ was dissolved in acetonitrile $(3 \mathrm{~mL})$ and added to a solution of 1-propanethiol $(0.08 \mathrm{~g}, 0.91 \mathrm{mmol}, 0.10 \mathrm{~mL})$ in acetonitrile $(2 \mathrm{~mL})$, containing an equimolar amount of triethylamine $(0.10 \mathrm{~g}$, $0.91 \mathrm{mmol}, 0.13 \mathrm{~mL}$ ). The solution was stirred for $18 \mathrm{~h}$ at $80^{\circ} \mathrm{C}$. It was then poured into water and the organic components were extracted with methylene chloride. The organic layer was dried $\left(\mathrm{MgSO}_{4}\right)$ and passed through a silica gel plug. The solvent was removed under reduced pressure and the residue was separated on a silica gel column (hexane $/ \mathrm{CH}_{2} \mathrm{Cl}_{2}$ in $1: 1$ ratio) to yield the product as pale yellow crystals $(0.10 \mathrm{~g}, 0.35 \mathrm{mmol}, 38 \%)$. In the $10 \mathrm{mmol}$ scale reaction, ester 16 was isolated from the crude mixture by short-path distillation $\left(170^{\circ} \mathrm{C} / 0.6\right.$ torr $)$ followed by recrystallization from methanol in the overall yield of 30\%: $\mathrm{mp} 60.5-61^{\circ} \mathrm{C}$; IR 2965, 1730, 1291, 1284, 1253, $1238,1206,750 \mathrm{~cm}^{-1}$; MS m/e (relative intensity) 290 $\left((\mathrm{M}+2)^{+}, 100\right), 288\left(\mathrm{M}^{+}, 96\right), 248$ (81), 246 (77). Anal.
Calcd for $\mathrm{C}_{11} \mathrm{H}_{13} \mathrm{BrO}_{2} \mathrm{~S}$ : C, 45.69; $\mathrm{H}, 4.53 ; \mathrm{S}, 11.09$. Found: C, 45.83; H, 4.51; S, 11.19.

2-Chloro-3-propylthioaniline (17). Nitro compound 3a $(1.82 \mathrm{~g}, 7.90 \mathrm{mmol})$ was dissolved in absolute ethanol $(50 \mathrm{~mL})$ in a hydrogenation bottle. $\mathrm{PtO}_{2}(0.18 \mathrm{~g}$, $0.78 \mathrm{mmol}$ ) was added and the resultant mixture was subjected to hydrogenation at $40-45 \mathrm{psi}$ for $6 \mathrm{~h}$ at ambient temperature followed by $1 \mathrm{~h}$ at $80^{\circ} \mathrm{C}$. The mixture was filtered through a Celite pad and the solvents were evaporated. The residue was redissolved in methylene chloride and passed through a silica gel plug to give the product as a colorless oil (1.43 g, 90\% yield), which was used without further purification: MS m/e (relative intensity) 203 $\left((\mathrm{M}+2)^{+}, 20\right), 201\left(\mathrm{M}^{+}, 35\right), 159$ (100), 124 (39).

2,6-Bis(propylthio)nitrobenzene (19). 2,6-Dichloroaniline $(12.32 \mathrm{~g}, 76 \mathrm{mmol})$, acetic acid $(300 \mathrm{~mL})$, hydrogen peroxide $(30 \%, 100 \mathrm{~mL})$ and sulfuric acid $(6 \mathrm{~mL})$ were stirred at $80^{\circ} \mathrm{C}$ for $8 \mathrm{~h}$. The resulting yellow solution was cooled, water $(1200 \mathrm{~mL})$ added and the precipitated product filtered and dried to give crude 2,6-dichloronitrobenzene (18,9.5 g). The crude product $18(2.16 \mathrm{~g}, 11 \mathrm{mmol})$ was added to a solution of 1-propanethiol $(1.77 \mathrm{~g}, 23 \mathrm{mmol})$ and $\mathrm{NaOH}$ $(0.93 \mathrm{~g}, 23 \mathrm{mmol})$ in ethanol $(25 \mathrm{~mL})$. The mixture was gently refluxed for $4 \mathrm{~h}$, poured into water and the product extracted with methylene chloride. Crude material was separated by flash column chromatography (hexane/ $\mathrm{CH}_{2} \mathrm{Cl}_{2}$ in $2: 5$ ratio) to give $1.20 \mathrm{~g}$ (28\% overall yield) of yellow solid of pure 19: $\mathrm{mp} 44-45^{\circ} \mathrm{C}$; IR 2960, 2926, 1569, 1533, 1439, $1362 \mathrm{~cm}^{-1}$; MS m/e (relative intensity) 271 $\left(\mathrm{M}^{+}, 11\right), 242$ (35), 182 (100), 122 (35). Anal. Calcd for $\mathrm{C}_{12} \mathrm{H}_{17} \mathrm{NO}_{2} \mathrm{~S}_{2}$ : C, 53.11; H, 6.31; N, 5.16. Found: C, 53.23; $\mathrm{H}, 6.48$; N, 5.15.

2,6-Bis(propylthio)aniline (20). Nitro compound 19 $(1.80 \mathrm{~g}, 6.60 \mathrm{mmol})$ was dissolved in glacial acetic acid $(30 \mathrm{~mL})$ and the solution was heated to $120^{\circ} \mathrm{C}$. Fine iron powder $(1.24 \mathrm{~g}, 22.10 \mathrm{mmol})$ was added in one portion and the mixture was stirred at $120^{\circ} \mathrm{C}$ for $2 \mathrm{~h}$. The hot mixture was poured into water and the organic materials were extracted with methylene chloride. The solvent was removed and the residue was passed through a silica gel column (hexane/ $\mathrm{CH}_{2} \mathrm{Cl}_{2}$ in 3:1 ratio) to give $0.90 \mathrm{~g}$ (56\% yield) of the product as a light oil: IR 3459, 3352, 2961, 2929, 2870, 1588, 1550, 1430, 1235, $736 \mathrm{~cm}^{-1}$; MS m/e (relative intensity) $241\left(\mathrm{M}^{+}, 100\right), 199$ (25), 157 (90), 155 (93), 124 (54). Anal. Calcd for $\mathrm{C}_{12} \mathrm{H}_{19} \mathrm{NS}_{2}$ : C, 59.70; H, 7.93; N, 5.80. Found: C, 59.45; H, 7.88; N, 5.63.

\section{Acknowledgements}

This project has been supported by NSF (CHE-9528029) and Vanderbilt University (V.B.). We thank Mr Daniel E. McBrayer and Mr Kristopher B. McNeil for their technical assistance.

\section{References}

1. Harris, N. V.; Smith, C.; Bowden, K. J. Med. Chem. 1990, 33, 434. 
2. Breslin, H. J.; Kukla, M. J.; Ludovici, D. W.; Mohrbacher, R.; Ho, W.; Miranda, M.; Rodgers, J. D.; Hitchens, T. K.; Leo, G.; Gauthier, D. A.; Ho, C. Y.; Scott, M. K.; De Clercq, E.; Pauwels, R.; Andries, K.; Janssen, M. A. C.; Janssen, P. A. J. J. Med. Chem. 1995, 38, 771 .

3. Lampe, J. W.; Hughes, P. F.; Biggers, C. K.; Smith, S. H.; Hu, H. J. Org. Chem. 1994, 59, 5147.

4. Saito, S.; Tamura, O.; Kobayashi, Y.; Matsuda, F.; Katoh, T.; Terashima, S. Tetrahedron 1994, 50, 6193.

5. Özlü, Y.; Cladingboel, D. E.; Parsons, P. J. Tetrahedron 1994, 50, 2183.

6. Rahman, L. K. A.; Scrowston, R. M. J. Chem. Soc., Perkin Trans. 1 1984, 385.

7. Sakamoto, T.; Kondo, Y.; Yamanaka, H. Chem. Pharm. Bull. 1986, 34, 2362.

8. Rewcastle, G. W.; Denny, W. A.; Baguley, B. C. J. Med. Chem. 1987, 30,843 .

9. Wensbo, D.; Gronowitz, S. Tetrahedron 1996, 52, 14975.

10. Kasahara, A.; Izumi, T.; Murakami, S.; Miyamoto, K.; Hino, T. J. Heterocyc. Chem. 1989, 26, 1405.

11. Krolski, M. E.; Renaldo, A. F.; Rudisill, D. E.; Stille, J. K. J. Org. Chem. 1988, 53, 1170.

12. Adams, R.; Finger, G. C. J. Am. Chem. Soc. 1939, 61, 2828.

13. Miyano, S.; Fukushima, H.; Handa, S.; Ito, H.; Hashimoto, H. Bull. Chem. Soc. Jpn. 1988, 61, 3249.

14. Takahashi, M.; Kuroda, T.; Ogiku, T.; Ohmizu, H.; Kondo, K.; Iwasaki, T. Heterocycles 1993, 36, 1867.

15. Sandos Ltd. Neth. Pat. Appl. 6,605,691; Chem. Abstr. 1967, 67, $90541 \mathrm{n}$.

16. Ando, M.; Emoto, S. Bull. Chem. Soc. Jpn. 1978, 51, 2437.

17. Kaszynski, P. In Magnetic Properties of Organic Materials; Lahti, P. M.; Ed.; Marcel Dekker: New York, 1999, pp 305-324.

18. Fanta, P. E. Synthesis 1974, 9.

19. Schultz, H. P. In Organic Synthesis; Rabjohn, N., Ed.; Wiley: New York, 1963; Vol. IV, p 364.

20. Whitmore, F. C.; Culhane, P. J.; Neher, H. T. In Organic Synthesis, Gilman, H., Blatt, T. Eds.; Wiley: New York, 1932; Vol. I, p 56.
21. Nicolaou, K. C.; Bunnage, M. E.; Koide, K. J. Am. Chem. Soc. 1994, 116, 8402 .

22. Parker, R. E.; Read, T. O. J. Chem. Soc. 1962, 3149.

23. Culhane, P. J. In Organic Synthesis; Gilman, H., Blatt, T., Eds.; Wiley: New York, 1932; Vol. I, p 125.

24. Rovnyak, G.; Andersen, N.; Gougoutas, J.; Hedberg, A.; Kimball, S. D.; Malley, M.; Moreland, S.; Porubcan, M.; Pudzianowski, A. J. Med. Chem. 1988, 31, 936.

25. Kanno, H.; Yamaguchi, H.; Okamiya, Y.; Sunakawa, K.; Takeshita, T.; Naruchi, T. Chem. Pharm. Bull. 1992, 40, 2049.

26. Bamfield, P.; Greenwood, D. Dyes and Pigments 1981, 2, 161. 27. The quality and the particle size of electrolytic iron are important factors imparting the yield of the reduction, which may be as low as $40 \%$ in some cases.

28. Sheppard, W. A. In Organic Synthesis; Baumgarten, H. E., Ed.; Wiley: New York, 1973; Vol. 5, p 843.

29. Stevens, C. L.; Singhal, G. H. J. Org. Chem. 1964, 29, 34.

30. Oae, S.; Price, C. C. J. Am. Chem. Soc. 1958, 80, 4938.

31. van Beek, L. K. H.; van Beek, J. R. G. C. M.; Boven, J.; Schoot, C. J. J. Org. Chem. 1971, 36, 2194.

32. Tona, M.; Sánchez-Baeza, F.; Messeguer, A. Tetrahedron 1994, $50,8117$.

33. Doyle, M. P.; Bryker, W. J. J. Org. Chem. 1979, 44, 1572.

34. Brokken-Zijp, J.; Bogaert, H. V. D. Tetrahedron 1973, 29, 4169.

35. Roe, A. M.; Burton, R. A.; Willey, G. L.; Baines, M. W.; Rasmussen, A. C. J. Med. Chem. 1968, 11, 814.

36. Holmes, R. R.; Bayer, R. P. J. Am. Chem. Soc. 1960, 82, 3454. 37. Loudon, J. D. J. Chem. Soc. 1940, 1525.

38. Akitt, J. W. NMR and Chemistry. An Introduction to Modern NMR Spectroscopy, 3rd ed.; Chapman \& Hall: New York, 1992.

39. Reichardt, C. Solvents and Solvent Effects in Organic Chemistry; VCH: New York, 1988.

40. Kitching, W.; de Jonge, I.; Adcock, W.; Abeywickrema, A. N. Org. Magn. Res. 1980, 14, 502.

41. Ströhl, D.; Thomas, S.; Kleinpeter, E.; Radeglia, R.; Brunn, J. Monatsh. Chem. 1992, 123, 769. 